\title{
Neuroprotection by Glial Metabotropic Glutamate Receptors Is Mediated by Transforming Growth Factor- $\beta$
}

\author{
V. Bruno, ${ }^{1}$ G. Battaglia, ${ }^{1}$ G. Casabona, ${ }^{1}$ A. Copani, ${ }^{2}$ F. Caciagli, ${ }^{3}$ and F. Nicoletti ${ }^{1,2}$ \\ 1/stituto Neurologico Mediterraneo Neuromed, 86077 Pozzilli, Italy, 2Institute of Pharmacology, School of Pharmacy, \\ University of Catania, 95125 Catania, Italy, and 'Department of Pharmacological Sciences, University of Chieti, 66013 \\ Chieti, Italy
}

The medium collected from cultured astrocytes transiently exposed to the group-II metabotropic glutamate (mGlu) receptor agonists $\left(2_{S}, 1_{R}{ }_{R}, 2^{\prime}{ }_{R}, 3^{\prime}{ }_{R}\right)-2-(2,3-$ dicarboxycyclopropyl)glycine (DCG-IV) or (S)-4-carboxy-3-hydroxyphenylglycine (4C3HPG) is neuroprotective when transferred to mixed cortical cultures challenged with NMDA (Bruno et al., 1997). The following data indicate that this particular form of neuroprotection is mediated by transforming growth factor- $\beta$ (TGF $\beta$ ). (1) TGF $\beta 1$ and $-\beta 2$ were highly neuroprotective against NMDA toxicity, and their action was less than additive with that produced by the medium collected from astrocytes treated with DCG-IV or 4C3HPG (GM/DCG-IV or GM/4C3HPG); (2) antibodies that specifically neutralized the actions of TGF $\beta 1$ or $-\beta 2$ prevented the neuro- protective activity of DCG-IV or 4C3HPG, as well as the activity of GM/DCG-IV or GM/4C3HPG; and (3) a transient exposure of cultured astrocytes to either DCG-IV or 4C3HPG led to a delayed increase in both intracellular and extracellular levels of TGF $\beta$. We therefore conclude that a transient activation of group-II mGlu receptors (presumably mGlu3 receptors) in astrocytes leads to an increased formation and release of TGF $\beta$, which in turn protects neighbor neurons against excitotoxic death. These results offer a new strategy for increasing the local production of neuroprotective factors in the CNS.

Key words: metabotropic glutamate receptors; glial cells; transforming growth factor- $\beta$; neuroprotection; excitotoxic neuronal death; astrocyte; cortical cultures
Metabotropic glutamate (mGlu) receptors form a family of eight subtypes (mGlu1-8), which have been subdivided into three groups. Group-I includes mGlu1 and -5 , which are coupled to polyphosphoinositide (PI) hydrolysis as well as to various classes of $\mathrm{K}^{+}$channels via a $\mathrm{G}_{\mathrm{o}}$ or $\mathrm{G}_{\mathrm{q}}$ GTP binding protein (for review, see Pin and Duvoisin, 1995). Group-II (mGlu2 and -3) and group-III (mGlu4, $-6,-7,-8)$ receptors are coupled to a $\mathrm{G}_{\mathrm{i}^{-}}$ protein, and their activation inhibits adenylyl cyclase activity in heterologous expression systems (Tanabe et al., 1992, 1993). However, native group-II or group-III mGlu receptors in the CNS are coupled to multiple transduction pathways, including inhibition of voltage-sensitive $\mathrm{Ca}^{2+}$ channels, stimulation or inhibition of cAMP formation, stimulation of PI hydrolysis, and activation of the mitogen-activated protein (MAP) kinase pathway (Winder and Conn, 1992; Genazzani et al., 1994; for review, see Pin and Duvoisin, 1995).

Recently, mGlu receptors have been considered a potential target for neuroprotective drugs. In particular, activation of group-II or group-III mGlu receptors protects neurons against excitotoxic death or other forms of degeneration (for review, see Nicoletti et al., 1996). However, the mechanism responsible for neuroprotection differs between these two classes of mGlu receptor subtypes. mGlu4, -7 , and -8 receptors are exclusively localized in neurons, and their activation inhibits glutamate release (Shigemoto et al., 1997). Hence, group-III mGlu receptor agonists are of potential value in the experimental therapy of epilepsy or neurodegenerative disorders of excitotoxic origin. In contrast,

Received July 6, 1998; revised Sept. 8, 1998; accepted Sept. 10, 1998.

Correspondence should be addressed to Dr. Ferdinando Nicoletti, Institute of Pharmacology, School of Pharmacy, University of Catania, Viale AA Doria 6, 95125 Catania, Italy.

Copyright (C) 1998 Society for Neuroscience $\quad 0270-6474 / 98 / 189594-07 \$ 05.00 / 0$ inhibition of glutamate release may contribute to, but is not sufficient to explain, neuroprotection mediated by group-II mGlu receptors. Accordingly, mGlu2 or -3 receptor agonists protect not only against excitotoxic death but also against apoptosis induced by $\beta$-amyloid peptide or hypoxia combined with glucose deprivation in the presence of a mixture of ionotropic receptor antagonists, i.e., under conditions in which neurodegeneration develops in the absence of any excitotoxic component (Buisson and Choi, 1995; Copani et al., 1995). We recently showed that neuroprotection mediated by group-II mGlu receptors involves a novel form of glial-neuronal interaction, which is promoted by the activation of mGlu3 receptors present in astrocytes (Bruno et al., 1997). The medium collected from cultured astrocytes 2-20 hr after a brief exposure to mGlu3 receptor agonists is highly neuroprotective against NMDA toxicity (Bruno et al., 1997, 1998). Neuroprotection is attenuated after treating the astrocytes with cycloheximide or after heating the medium, suggesting that astrocytes produce and release a proteic neuroprotective factor in response to mGlu3 receptor activation (Bruno et al., 1997). This novel mechanism may offer a new strategy to increase the local production of neurotrophic factors in the CNS. We now demonstrate that neuroprotection by glial mGlu3 receptors is mediated by transforming growth factor- $\beta 1$ (TGF $\beta 1$ ) and TGF $\beta 2$, which are released from astrocytes and exert a potent neuroprotective activity in in vitro and in vivo models of excitotoxic death.

\section{MATERIALS AND METHODS}

Mixed cortical cultures. Mixed cortical cultures containing both neurons and astrocytes were prepared from fetal mice at $14-16 \mathrm{~d}$ of gestation, as described by Rose et al. (1992). In brief, dissociated cortical cells were plated in $15 \mathrm{~mm}$ multiwell vessels (Falcon Primaria, Lincoln Park, NY) on a layer of confluent astrocytes [prepared as described by Rose et al. (1992)], using a plating medium of MEM-Eagle's salts (supplied 
glutamine-free) supplemented with $5 \%$ heat-inactivated horse serum, $5 \%$ fetal bovine serum, glutamine (2 mM), glucose $(21 \mathrm{~mm})$, and $\mathrm{NaHCO}_{3}(25 \mathrm{~mm})$. After 3-5 d in vitro (DIV), non-neuronal cell division was halted by a $1-3 \mathrm{~d}$ exposure to $10 \mu \mathrm{M}$ cytosine arabinoside, and cultures were shifted to a maintenance medium identical to plating medium but lacking fetal bovine serum. Subsequent partial medium replacement was performed twice a week. Cultures at 13-14 DIV were used.

Glial cultures. Glial cell cultures were prepared from postnatal mice (1-3 d after birth), as described previously (Rose et al., 1992). Dissociated cortical cells were grown in $15 \mathrm{~mm}$ multiwell vessels using a plating medium of MEM-Eagle's salts supplemented with $10 \%$ of heatinactivated horse serum, $10 \%$ fetal bovine serum, $2 \mathrm{~mm}$ glutamine, sodium bicarbonate $(25 \mathrm{~mm})$, and glucose $(21 \mathrm{~mm})$. Cultures were kept at $37^{\circ} \mathrm{C}$ in a humidified $\mathrm{CO}_{2}$ atmosphere until they reached confluency (7-14 DIV). Confluent cultures were then used for the experiments or as a support for mixed cultures.

Assessment of neuronal death in culture. For induction of excitotoxic death, mixed cultures were exposed to NMDA for $10 \mathrm{~min}$ at room temperature in a HEPES-buffered salt solution containing (in $\mathrm{mM}$ ): 120 $\mathrm{NaCl}, 5.4 \mathrm{KCl}, 0.8 \mathrm{MgCl}_{2}, 1.8 \mathrm{CaCl}_{2}, 20 \mathrm{HEPES}$, and 15 glucose. Afterward, the cultures were extensively washed and incubated in MEMEagle's (supplemented with $25 \mathrm{~mm} \mathrm{NaHCO}_{3}$ and $21 \mathrm{~mm}$ glucose) (MS) at $37^{\circ} \mathrm{C}$. In some experiments, glial conditioned medium (GM) was added to the cultures immediately after the NMDA pulse and maintained during the following $24 \mathrm{hr}$ of incubation. GM was prepared as follows. Glial cortical cultures were exposed for $10 \mathrm{~min}$ to group-II mGlu receptor agonists, and then drugs were washed out and cultures were kept in MS (which does not contain serum) at $37^{\circ} \mathrm{C}$ for the following $20 \mathrm{hr}$. At the end of this incubation, the medium was collected and immediately transferred to mixed cultures.

Neuronal injury was estimated by examining the cultures with phasecontrast microscopy $24 \mathrm{hr}$ after the insult, when the process of cell death was largely complete. Neuronal damage was quantitatively assessed by trypan blue staining. Stained neurons were counted from three random fields per well. Neuronal injury was also assessed by measuring the activity of lactate dehydrogenase (LDH) into the extracellular medium, as described in Koh and Choi (1987).

Western blot analysis. Cultured astrocytes were harvested at $4^{\circ} \mathrm{C}$ in a 10 mM Tris buffer, $\mathrm{pH} 7.4$, containing 5 mM EDTA, $1 \mathrm{~mm}$ PMSF, $25 \mu \mathrm{g} / \mathrm{ml}$ leupeptin, and $0.5 \%$ aprotinin. After sonication, samples were centrifuged at $8000 \mathrm{rpm}$ for $10 \mathrm{~min}$, and an aliquot of the supernatants was processed for the assessment of protein concentration by the Bredford method. Samples were diluted in SDS-bromophenol blue buffer and boiled for 5 min before loading. Electrophoresis was performed in $15 \%$ SDS-PAGE using $40 \mu \mathrm{g}$ of total protein per lane. After separation, proteins were transferred onto a nitrocellulose membrane (Hybond ECL) for 35 min using a Bio-Rad transblot system (Bio-Rad, Munchen, Germany). After blocking, membranes were incubated with primary antibodies for $1 \mathrm{hr}$ at room temperature and then repeatedly washed and exposed to horseradish peroxidase-conjugated secondary antibodies for 1 $\mathrm{hr}$ at room temperature. Proteins were visualized using the enhancing chemiluminescence detection system (ECL). The following primary antibodies were used: rabbit polyclonal TGF $\beta 2$ antibody (Santa Cruz Biotechnology, Tebu, France) (final dilution: $500 \mathrm{ng} / \mathrm{ml}$ ) and monoclonal anti-actin antibody (Sigma, St. Louis, MO) (1:1000 dilution).

Measurement of TGF $\beta$ in the astrocyte medium. The amount of TGF $\beta$ released from cultured astrocytes in the medium was measured by using a sensitive bioassay based on the ability of TGF $\beta$ to reduce the proliferation rate of mink lung cells. Mink lung cells were purchased from American Type Culture Collection and plated in $15 \mathrm{~mm}$ multiwell vessels (Falcon Primaria) using a plating medium of DMEM containing $0.1 \mathrm{~mm}$ nonessential amino acids, $1 \mathrm{~mm}$ sodium pyruvate, $2 \mathrm{~mm}$ glutamine, and $10 \%$ fetal bovine serum. Twenty-four hours after plating, cells were exposed to $\mathrm{GM}$ in the presence of $0.5 \mu \mathrm{Ci} /$ well of [methyl${ }^{3} \mathrm{H}$ ] thymidine at $37^{\circ} \mathrm{C}$ for $24 \mathrm{hr}$. [Methyl $-{ }^{3} \mathrm{H}$ ] thymidine incorporation has been assessed as described by Ciccarelli et al. (1997). Standard curves were constructed by using concentrations of human recombinant TGF $\beta 1$ or $-\beta 2$ ranging from $0.1 \mathrm{pg} / \mathrm{ml}$ to $10 \mathrm{ng} / \mathrm{ml}$.

The amount of TGF $\beta 1$ present in the GM was also assessed by the TGF $\beta 1 \mathrm{E}_{\max }$ ELISA System (Promega) which is designed to specifically detect biologically active TGF $\beta 1$.

Assessment of in vivo neuronal injury. Male Sprague Dawley rats (250-300 gm, body weight) were anesthetized with pentobarbital (50 $\mathrm{mg} / \mathrm{kg}$, i.p.) and infused with NMDA $(100 \mathrm{nmol} / 0.5 \mu \mathrm{l}$ per $2 \mathrm{~min})$ or
Table 1. Neuroprotection by the medium collected from glial cultures 2 or $20 \mathrm{hr}$ after a transient exposure to group-II mGlu receptor agonists

\begin{tabular}{lcc} 
& \multicolumn{2}{l}{ NMDA toxicity } \\
\cline { 2 - 3 } & Number of dead cells & $\begin{array}{c}\text { LDH release } \\
\text { (mO.D./min) }\end{array}$ \\
\hline Basal & $7 \pm 0.7$ & $15 \pm 7$ \\
NMDA, 100 $\mu \mathrm{M}$ & $155 \pm 9$ & $119 \pm 8$ \\
$+\mathrm{GM} /$ control, $2 \mathrm{hr}$ & $168 \pm 11$ & $116 \pm 22$ \\
$+\mathrm{GM} /$ control, 20 hr & $183 \pm 24$ & $104 \pm 17$ \\
$+\mathrm{GM} / \mathrm{DCG}-\mathrm{IV}, 2 \mathrm{hr}$ & $67 \pm 7^{*}$ & $59 \pm 9^{*}$ \\
$+\mathrm{GM} / \mathrm{DCG}-\mathrm{IV}, 20 \mathrm{hr}$ & $74 \pm 15^{*}$ & $57 \pm 6^{*}$ \\
$+\mathrm{GM} / 4 \mathrm{C} 3 \mathrm{HPG}, 2 \mathrm{hr}$ & $71 \pm 9^{*}$ & $63 \pm 11^{*}$ \\
$+\mathrm{GM} / 4 \mathrm{C} 3 \mathrm{HPG}, 20 \mathrm{hr}$ & $56 \pm 5^{*}$ & $60 \pm 8^{*}$ \\
\hline
\end{tabular}

$\overline{\text { Values are means } \pm \text { SEM of } 12-16 \text { determinations. }{ }^{*} p<0.01 \text { (one-way ANOVA }+}$ Fisher PLSD) versus NMDA alone. GM/control, Glial medium (GM) collected 2 or $20 \mathrm{hr}$ after a $10 \mathrm{~min}$ exposure of pure cultures of astrocytes to the buffer alone; GM/DCG-IV and GM/4C3HPG, medium collected after a $10 \mathrm{~min}$ exposure of cultured astrocytes to $1 \mu \mathrm{m}$ DCG-IV or $100 \mu \mathrm{M} 4 \mathrm{C} 3 \mathrm{HPG}$. Collected medium was transferred to mixed cultures immediately after the toxic pulse with NMDA and maintained for the following $20 \mathrm{hr}$. The astrocyte medium did not affect neuronal viability in the absence of NMDA (data not shown). The number of dead cells was determined by counting neurons stained with trypan blue in three random microscopic fields. See Bruno et al. (1997) for a more detailed characterization. mO.D., Milli-Optical density.

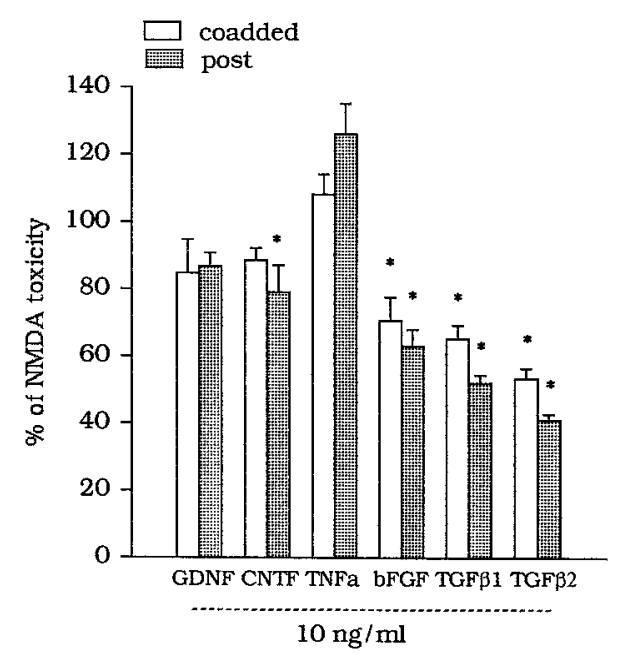

Figure 1. Effect of trophic factors on NMDA toxicity in mixed cultures of cortical cells. Factors were either combined with NMDA (coadded) or applied to the cultures immediately after the NMDA pulse and maintained in the medium during the following $20 \mathrm{hr}$ (post). Values are means \pm SEM of four to six determinations from two different multiplates and were calculated from the counts of neurons stained with trypan blue. Results were virtually identical when calculated from the extracellular LDH activity, which was always measured in parallel. In each multiplate, the mean of values obtained from individual dishes treated with NMDA alone, after subtracting the basal values, was considered as $100 \%$ or NMDA toxicity. Each individual determination was expressed as percentage of NMDA toxicity, always after subtracting the respective basal values. The SD calculated from the original counts of neurons stained with trypan blue was always $<10 \%$ of the mean value for each experimental group. ${ }^{*} p<0.01$ (one-way ANOVA + Fisher PLSD), if compared with values obtained with NMDA alone.

NMDA + TGF $\beta 1$ or $-\beta 2(0.5 \mathrm{ng} / 0.5 \mu \mathrm{l})$ in the left caudate nucleus, at $+2.0 \mathrm{~mm}$ anteroposterior (AP), $2.6 \mathrm{~mm}$ lateral (L), and $5 \mathrm{~mm}$ ventral (V), according to the Pellegrino and Cushman (Pellegrino et al., 1992) atlas. The injection was repeated at a second site $(+1 \mathrm{~mm} \mathrm{AP,} 2.6 \mathrm{~mm} \mathrm{~L}$, and $5 \mathrm{~mm} \mathrm{~V}$ ) to obtain a more consistent loss of striatal neurons. Animals were killed by decapitation $7 \mathrm{~d}$ later. Neuronal toxicity was evaluated either by histological examination or by measuring striatal glutamate 


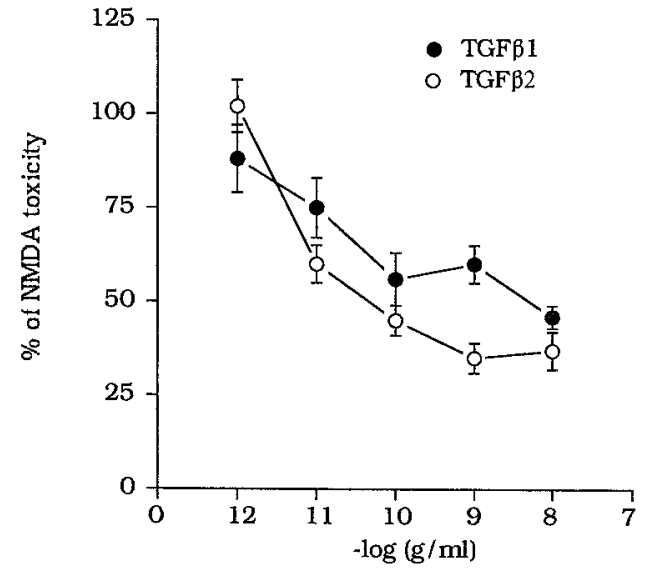

Figure 2. Concentration-dependent neuroprotection by TGF $\beta 1$ or $-\beta 2$ against NMDA toxicity in mixed cultures of cortical cells. TGF $\beta 1$ or $-\beta 2$ were applied immediately after the NMDA pulse and maintained in the medium during the following $20 \mathrm{hr}$. Values are means \pm SEM of four individual determinations and were calculated from the counts of neurons stained with trypan blue, as described in Figure 1.

decarboxylase (GAD) activity as a marker for GABAergic neurons. For histological analysis, the brains were removed, frozen rapidly in isopentane at $-40^{\circ} \mathrm{C}$, and then stored at $-80^{\circ} \mathrm{C}$. Cryostat sections $(20 \mu \mathrm{m})$ were Nissl-stained and examined in light microscopy. For measurements of GAD activity, the corpus striatum was dissected bilaterally and homogenized in $5 \mathrm{~mm}$ imidazol buffer containing $0.2 \%$ Triton X-100 and $10 \mathrm{~mm}$ dithiothreitol. An aliquot of the homogenate was incubated in $400 \mu \mathrm{l}$ of $10 \mathrm{~mm}$ phosphate buffer, $\mathrm{pH}$ 7.0, containing $10 \mathrm{~mm}$ 2-mercaptoethanol, $0.02 \mathrm{~mm}$ pyridoxalphosphate, and $1 \mu \mathrm{Ci}$ of $\left[{ }^{3} \mathrm{H}\right]$-glutamate (Amersham; specific activity $46 \mathrm{Ci} / \mathrm{mmol}$ ) for $1 \mathrm{hr}$ at $37^{\circ} \mathrm{C}$; the reaction was stopped with $15 \mu \mathrm{l}$ of ice-cold $11.8 \mathrm{~N} \mathrm{HClO}_{4}$. After centrifugation in a microf uge at maximal speed, $10 \mu \mathrm{l}$ of the supernatant was diluted with $0.01 \mathrm{~N} \mathrm{HCl}$ and derivatized with O-phthalaldehyde and mercaptoethanol for $1 \mathrm{~min}$ at room temperature before injection into HPLC. The HPLC apparatus consisted of a programmable solvent module 126 (Beckman Instruments, Fullerton CA), an analytical C-18 reverse-phase column kept at $30^{\circ} \mathrm{C}$ (Ultrasphere ODS $5 \mu \mathrm{m}$ spherical, 80 A pore, $2 \mathrm{~mm} \times 15 \mathrm{~cm}$; Beckman Instruments), and an RF-551 spectrofluorometric detector (Shimadzu). Excitation and emission were set at 360 and $450 \mathrm{~nm}$, respectively. The mobile phase consisted of (1) $50 \mathrm{~mm}$ sodium phosphate/10\% methanol, $\mathrm{pH} 7.2$, and (2) $50 \mathrm{~mm}$ sodium phosphate $/ 70 \%$ methanol, $\mathrm{pH}$ 7.2. After 8 min of isocratic conditions with $98 \%$ (1) and $2 \%$ (2), (2) was increased up to $40 \%$ in $30 \mathrm{~min}$ and then to $98 \%$ in $1 \mathrm{~min}$ and maintained at $98 \%$ for $11 \mathrm{~min}$ before returning to the initial conditions. The radioactivity coeluting with GABA was collected and counted by scintillation spectrometry. Protein concentrations in the original samples were determined by using a commercially available kit (Bio-Rad protein assay).

Materials. Ciliary neurotrophic factor (CNTF), glial-derived neurotrophic factor (GDNF), basic fibroblast growth factor (bFGF), tumor necrosis factor- $\alpha$ (TNF- $\alpha$ ), and human recombinant TGF $\beta 1$ or $-\beta 2$ were purchased from Sigma. Antibodies specific for TGF $\beta 1$ (catalog \#sc-146) or TGF $\beta 2$ (catalog \#sc-90) were purchased from Santa Cruz Biotechnology. Both antibodies are reactive against human, rat, and mouse TGF $\beta 1$ or -2. DCG-IV, 4C3HPG, L-2-amino-4-phosphonobutanoic acid (L-AP4), and NMDA were purchased from Tocris Cookson.

\section{RESULTS}

\section{TGF $\beta$ protects cultured neurons against excitotoxic death and mediates neuroprotection by glial group-II mGlu receptors}

A 10 min exposure of mixed cortical cultures to $100 \mu \mathrm{M}$ NMDA produced the delayed degeneration of $\sim 80 \%$ of the neuronal population (Table 1). NMDA toxicity was attenuated by the medium collected from pure cultures of astrocytes (GM) 2 or 20 hr after a $10 \mathrm{~min}$ exposure to $1 \mu \mathrm{M}$ DCG-IV (GM/DCG-IV) or $100 \mu \mathrm{M}$ 4C3HPG (GM/4C3HPG) [Table 1; see Bruno et al.
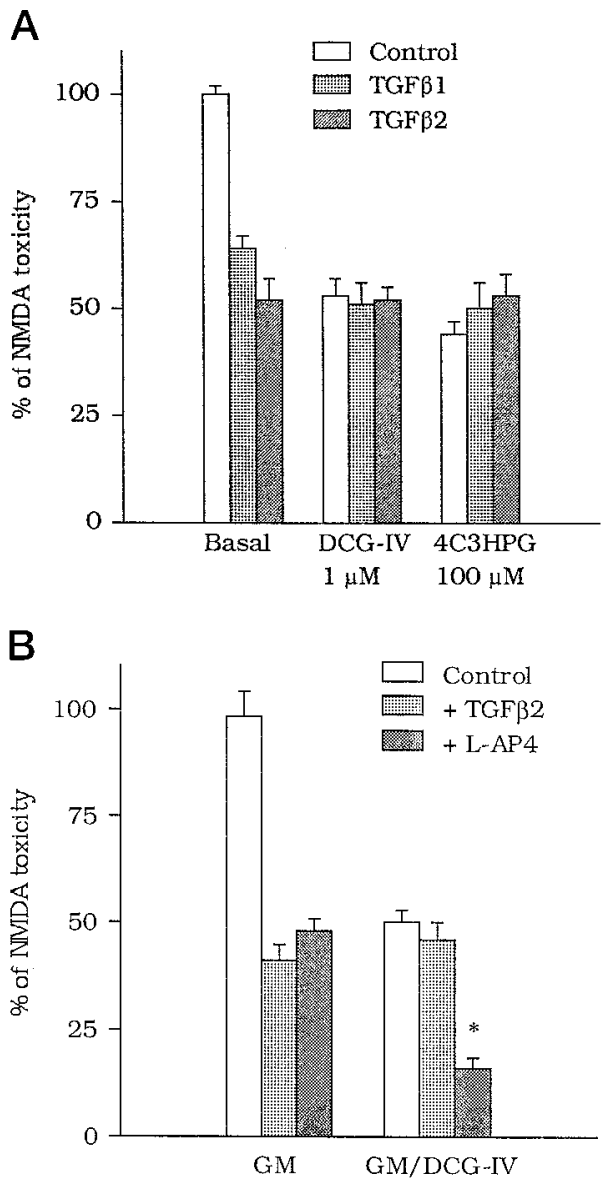

Figure 3. $A$, Lack of additive effects between TGF $\beta 1$ or $-\beta 2$ and group-II mGlu receptor agonists on NMDA toxicity in mixed cortical cultures. DCG-IV $(1 \mu \mathrm{M})$ or 4C3HPG $(100 \mu \mathrm{M})$ were applied in combination with NMDA, whereas TGF $\beta 1$ or $-\beta 2$ (both at $1 \mathrm{ng} / \mathrm{ml}$ ) were applied after the NMDA pulse. Values are means \pm SEM of four determinations. $B$, The neuroprotective activity of TGF $\beta 2(1 \mathrm{ng} / \mathrm{ml})$ is obliterated when the factor is combined with the glial medium collected $20 \mathrm{hr}$ after a $10 \mathrm{~min}$ exposure to $1 \mu \mathrm{M}$ DCG-IV (GM/DCG-IV). Note that the protective activity of L-AP4 $(100 \mu \mathrm{M})$ is instead additive to that produced by the medium of DCG-IV-treated astrocytes. GM, Glial medium. Values are means \pm SEM of four determinations. ${ }^{*} p<0.01$ (one-way ANOVA + Fisher PLSD) if compared with the respective controls. In $A$ and $B$, values were calculated from the counts of neurons stained with trypan blue, as described in Figure 1.

(1997) for a more detailed characterization]. We started the search for the neuroprotective agent present in the GM/DCG-IV or GM/4C3HPG by screening a number of trophic factor for their neuroprotective activity against NMDA toxicity. Factors were either combined with NMDA for 10 min or applied immediately after the NMDA pulse and then maintained in the medium for the following $20 \mathrm{hr}$. Under both conditions, TGF $\beta 1$ and $-\beta 2$ displayed the highest neuroprotective activity, followed by that of bFGF. GDNF, CNTF, and TNF- $\alpha$ produced little, if any, neuroprotection (Fig. 1). We have not examined the effect of nerve growth factor or other neurotrophins, because they are reported not to affect or even amplify NMDA toxicity in mixed cortical cultures (Koh et al., 1995).

TGF $\beta 1$ and $-\beta 2$ were equipotent as neuroprotectants against NMDA toxicity, and their efficacy was essentially similar (Fig. 2). TGF $\beta 1$ or $-\beta 2$ did not produce any further neuroprotection when combined with DCG-IV or 4C3HPG (Fig. $3 A$ ) or with GM/ 

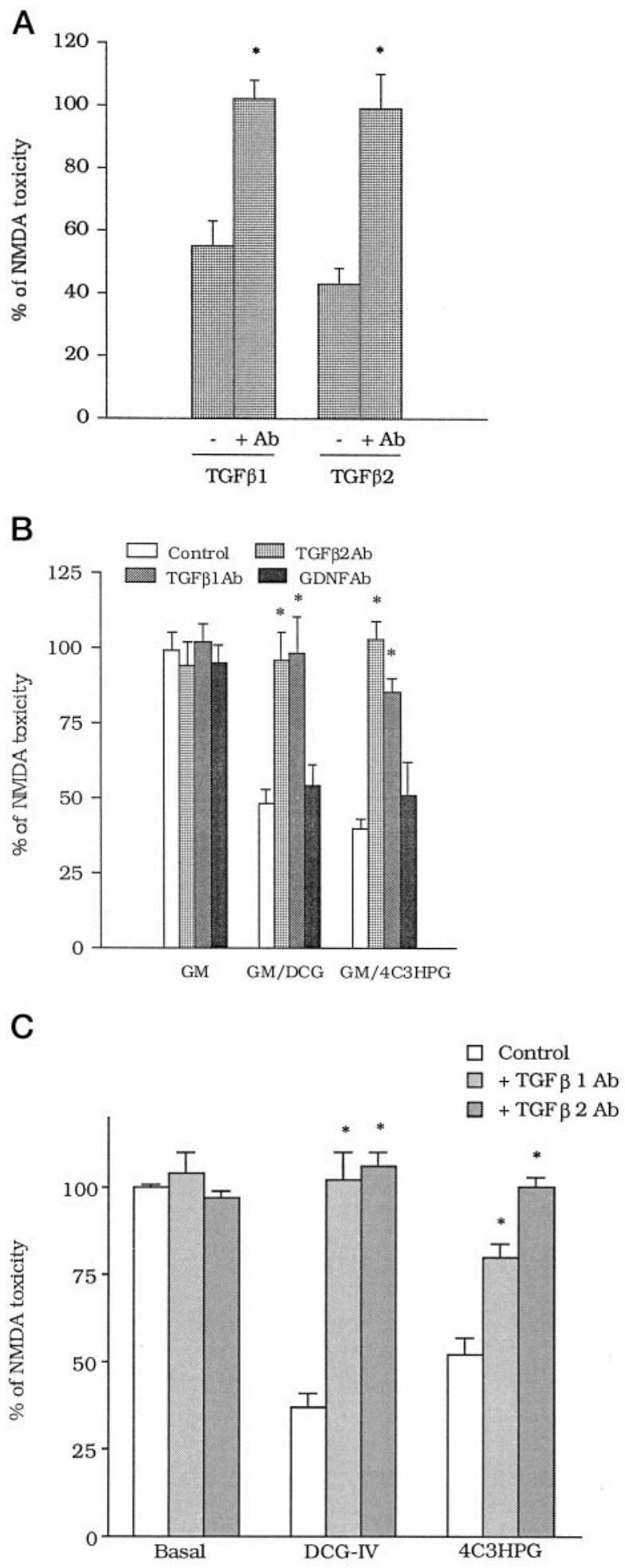

Figure 4. $A$, Antibodies $(A b)$ specific for TGF $\beta 1$ or $-\beta 2$ (both at 100 $\mathrm{ng} / \mathrm{ml}$ ) abolish the neuroprotective activity of TGF $\beta 1$ and $-\beta 2$ (both at 10 $\mathrm{ng} / \mathrm{ml}$ ) in mixed cortical cultures. Each of the factors and the respective antibody were added to the cultures immediately after the NMDA pulse and maintained in the medium during the following $20 \mathrm{hr}$. The concentration of antibodies was $100 \mathrm{ng} / \mathrm{ml}$. Values are means \pm SEM of eight determinations from two different experiments. ${ }^{*} p<0.01$ (Student's $t$ test), if compared with the respective values obtained in the absence of the antibody. TGF $\beta 1 \mathrm{Ab}$ at least did not prevent neuroprotection induced by bFGF applied after the NMDA pulse [bFGF, $10 \mathrm{ng} / \mathrm{ml}=70 \pm 3.5$; $\mathrm{bFGF}+\operatorname{TGF} \beta 1 \mathrm{Ab}(100 \mathrm{ng} / \mathrm{ml})=66 \pm 4.2$; TGF $\beta 1 \mathrm{Ab}$ alone $=92 \pm 6.3$;
DCG-IV (Fig. 3B). In contrast, the neuroprotective activity of L-AP4 $(100 \mu \mathrm{M})$ was additive with that produced by GM/ DCG-IV (Fig. 3B).

We used antibodies specific for TGF $\beta 1$ or $-\beta 2$ (TGF $\beta 1 \mathrm{Ab}$ or TGF $\beta 2 \mathrm{Ab}$ ), which were able to neutralize the neuroprotective activity of exogenously applied TGF $\beta 1$ or $-\beta 2$ (Fig. $4 A$ ) but not that of bFGF (see legend of Fig. $4 A$ ). TGF $\beta 1 \mathrm{Ab}$ or TGF $\beta 2 \mathrm{Ab}$ added to the GM/DCG-IV or GM/4C3HPG abolished neuroprotection, whereas a neutralizing antibody against GDNF was inactive (Fig. 4B). Interestingly, TGF $\beta 1 \mathrm{Ab}$ and TGF $\beta 2 \mathrm{Ab}$ also prevented the neuroprotective activity of group-II mGlu receptor agonists applied in combination with NMDA (Fig. 4C).

We therefore examined whether astrocytes treated with group-II mGlu receptor agonists release TGF $\beta$ into the medium by using a highly sensitive and specific bioassay, based on the ability of TGF $\beta$ to reduce the proliferation rate of mink lung epithelial cells. The control GM (i.e., the medium collected from astrocytes $20 \mathrm{hr}$ after simple addition of the buffer) showed an antiproliferative activity corresponding to that produced by 5 $\mathrm{pg} / \mathrm{ml}$ of authentic human TGF $\beta 1$ or $-\beta 2$. This activity increased several-fold $20 \mathrm{hr}$ after a $10 \mathrm{~min}$ exposure to DCG-IV or 4C3HPG (Table 2). These results were confirmed by measuring the extracellular levels of TGF $\beta 1$ by ELISA (medium from control astrocytes $=6.4 \pm 0.32 \mathrm{pg} / \mathrm{ml}$; medium from astrocytes treated with $4 \mathrm{C} 3 \mathrm{HPG}=38 \pm 0.45 \mathrm{pg} / \mathrm{ml}$ ).

Finally, we measured the intracellular levels of TGF $\beta 2$ in response to group-II mGlu receptor activation in astrocytes. Immunoblots of cultured astrocytes showed a single band of 24-25 kDa, corresponding to the dimeric form of TGF $\beta$ (Fig. 5). In control astrocytes, the intensity of this band decreased from 2 to $10 \mathrm{hr}$ after a $10 \mathrm{~min}$ treatment with buffer followed by incubation in serum-free medium. The intracellular levels of dimeric TGF $\beta 2$ were substantially higher 2 or $10 \mathrm{hr}$ after treating the cultures with DCG-IV (Fig. 6). A similar increase in TGF $\beta 2$ was induced by the A1 adenosine receptor agonist 2-chloro- $N^{6}$ cyclopentyladenosine (CCPA) (Fig. 5).

\section{Neuroprotective activity of TGF $\beta$ against in vivo excitotoxicity}

In animals inf used with NMDA alone (100 nmol/0.5 $\mu \mathrm{l}$ per $2 \mathrm{~min}$; double injection) in the left caudate nucleus, histological analysis showed an extensive necrotic region at the injection sites and neuronal loss, reactive gliosis, and edema in the surrounding tissue. In animals coinf used with NMDA and $0.5 \mathrm{ng}$ of TGF $\beta 1$ or $-\beta 2$, the extension of the necrotic area was smaller, and the

\footnotetext{
$\leftarrow$

$n=4$, expressed as percentage of NMDA toxicity]. $B$, TGF $\beta 1 \mathrm{Ab}$ and TGF $\beta 2 \mathrm{Ab}$ (both at $100 \mathrm{ng} / \mathrm{ml}$ ) prevent the neuroprotective activity of the glial medium collected $20 \mathrm{hr}$ after treating cultured astrocytes with $1 \mu \mathrm{M}$ DCG-IV (GM/DCG-IV) or $100 \mu \mathrm{M} 4 \mathrm{C} 3 \mathrm{HPG}(G M / 4 C 3 H P G)$. Note that antibodies against GDNF (GDNFAb, $100 \mathrm{ng} / \mathrm{ml})$ are inactive. All antibodies were applied to the glial medium before it was transferred to mixed cortical cultures. Values are means \pm SEM of eight determinations from two different experiments; ${ }^{*} p<0.01$ (one-way ANOVA + Fisher PLSD) if compared with the respective controls. $C$, TGF $\beta 1 \mathrm{Ab}$ and TGF $\beta 2 \mathrm{Ab}$ (all at $100 \mathrm{ng} / \mathrm{ml}$ ) reduce the neuroprotective activity of group-II mGlu receptor agonists in mixed cortical cultures. DCG-IV $(1 \mu \mathrm{M})$ or $4 \mathrm{C} 3 \mathrm{HPG}$ $(100 \mu \mathrm{M})$ were applied to the cultures during the $10 \mathrm{~min}$ pulse with NMDA. Antibodies were applied immediately after the pulse and maintained in the medium during the following $20 \mathrm{hr}$. Values are means \pm SEM of four determinations. ${ }^{*} p<0.01$ (one-way ANOVA + Fisher PLSD), if compared with the respective controls. In $A-C$, values were calculated from the counts of neurons stained with trypan blue, as described in Figure 1.
} 
Table 2. A transient activation of group-II mGlu receptors increases the extracellular levels of TGF $\beta$ in cultured astrocytes

\begin{tabular}{lll} 
& $\begin{array}{l}\text { TGF } \beta 1 \text {-like activity } \\
\text { (arbitrary units) }\end{array}$ & $\begin{array}{l}\text { TGF } \beta 2-\text { like activity } \\
\text { (arbitrary units) }\end{array}$ \\
\hline Control astrocytes & $1.0 \pm 0.31$ & $1.0 \pm 0.18$ \\
DCG-IV/astrocytes & $7.1 \pm 0.42^{*}$ & $4.5 \pm 0.25^{*}$ \\
4C3HPG/astrocytes & $6.9 \pm 0.51^{*}$ & $5.9 \pm 0.69^{*}$
\end{tabular}

Values are means \pm SEM from 12 individual determinations. ${ }^{*} p<0.01$ (one-way ANOVA + Fisher PLSD), if compared with control astrocytes. TGF $\beta 1$ - or TGF $\beta 2$ like activity was determined by measuring the ability of the medium to reduce $\left[{ }^{3} \mathrm{H}\right]$ thymidine incorporation in mink lung epithelial cells. One arbitrary unit corresponds to the antiproliferative activity produced by $5 \mathrm{pg} / \mathrm{ml}$ of authentic human TGF $\beta 1$ or $-\beta 2$. Values were calculated from reference curves constructed with authentic human TGF $\beta 1$ and - $\beta 2$ (from 0.1 to $10,000 \mathrm{pg} / \mathrm{ml}$ ). Maximal concentrations of TGF $\beta 1$ or $-\beta 2\left(300-1000 \mathrm{pg} / \mathrm{ml}\right.$ in different assays) reduced $\left[{ }^{3} \mathrm{H}\right]$ thymidine incorporation by $70-80 \%$. The different numbers between TGF $\beta 1$ - and TGF $\beta 2$-like activities reflect the slightly different potency we have found between authentic TGF $\beta 1$ and $-\beta 2$ in reducing $\left[{ }^{3} \mathrm{H}\right]$ thymidine incorporation. bFGF failed to reduce $\left[{ }^{3} \mathrm{H}\right]$ thymidine incorporation in mink lung epithelial cells $\left[\left[{ }^{3} \mathrm{H}\right]\right.$ thymidine incorporation $(\mathrm{cpm} / \mathrm{well})$ : basal $=28840 \pm 1737$; TGF $\beta 1,300 \mathrm{pg} / \mathrm{ml}=6900 \pm 2349 ; \mathrm{bFGF}$, $3 \mathrm{ng} / \mathrm{ml}=34560 \pm 4510 ; n=4]$.

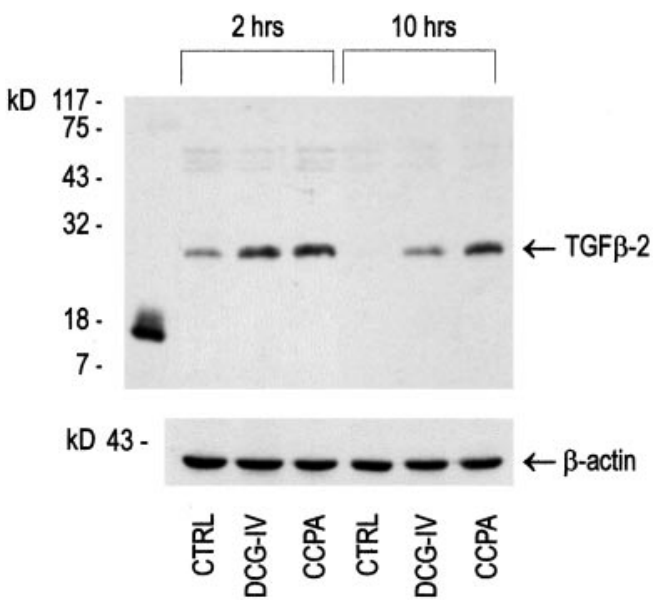

Figure 5. Western blot analysis of TGF $\beta 2$ in protein extracts from cultured astrocytes transiently exposed to $1 \mu \mathrm{M}$ DCG-IV or to $100 \mathrm{nM}$ CCPA. CTRL, Control astrocyte cultures treated with buffer alone for 10 $\mathrm{min}$, and then incubated for 2 or $10 \mathrm{hr}$ in serum-free medium (see Materials and Methods); $D C G-I V$, cultures treated for 10 min with $1 \mu \mathrm{M}$ DCG-IV and then incubated for 2 or $10 \mathrm{hr}$ in serum-free medium; $C C P A$, cultures treated for $10 \mathrm{~min}$ with CCPA and then incubated for 2 or $10 \mathrm{hr}$ in serum-free medium. Expression of $\beta$-actin is shown in the same protein extracts. Authentic monomeric human TGF $\beta 2$ is shown in the first lane.

neuronal loss in the surrounding tissue was substantially reduced (Fig. 6A-F). We have quantified the protective activity of TGF $\beta 1$ or $-\beta 2$ by measuring striatal GAD activity, which reflects the survival of GABAergic projection neurons and interneurons. Infusion of TGF $\beta 1$ or $-\beta 2$ prevented the reduction in striatal GAD activity induced by NMDA (Fig. $6 G$ ). Intrastriatal infusion of TGF $\beta 1$ or $-\beta 2$ alone did not produce significant changes in GAD activity after $7 \mathrm{~d}$ (data not shown).

\section{DISCUSSION}

The novel selective group-II mGlu receptor agonist LY354740 protects pure neuronal cultures against excitotoxic death, but only at concentrations higher than those sufficient to interact with mGlu2 or -3 receptors (Kingston et al., 1977). This casts doubt on the role of group-II mGlu receptors in neuroprotection, although several reports show a clear-cut protective activity of mGluR2/3 receptor agonists (for review, see Nicoletti et al., 1996). We suggest that it is the presence of astrocytes that enables neuroprotection by group-II mGlu receptor agonists. Accordingly, a brief exposure of glial cultures to the mGlu2/3 agonists DCG-IV, $4 \mathrm{C} 3 \mathrm{HPG}$, or $\left(2 S, 1^{\prime} S, 2^{\prime} S\right)$-2-(carboxycyclopropyl)glycine, or to the selective mGlu3 receptor agonist $\alpha$-N-acetylaspartylglutamate renders the medium neuroprotective against excitotoxic death (Bruno et al., 1997, 1998). This protective activity is abolished after heating the medium or after treating the astrocytes with the protein synthesis inhibitor cycloheximide (Bruno et al., 1997). Hence, we have hypothesized that astrocytes treated with mGlu3 receptor agonists produce and release a proteic neuroprotective factor. Present results identify this factor with TGF $\beta$, although they cannot exclude the possibility that other factors are produced, the activity of which depends on TGF $\beta$.

TGF $\beta 1$ and $-\beta 2$ showed a substantial neuroprotective activity in vitro and in vivo, which, unexpectedly, was greater than that exhibited by established neurotrophic factors such as GDNF or CNTF. The protective activity of TGF $\beta$ is in agreement with several recent reports (Prehn et al., 1994, 1996; Prehn, 1996; Ren and Flanders, 1996; Buisson et al., 1997) [but see also Kane et al. (1996)]. Protection by TGF $\beta 1$ or $-\beta 2$ was obscured by the medium collected from astrocytes treated with DCG-IV, and not because the response was saturated: the group-III mGlu receptor agonist L-AP4 could in fact further enhance the protective activity of the glial medium.

Untreated astrocytes released a low amount of TGF $\beta$ into the medium $(\sim 5 \mathrm{pg} / \mathrm{ml})$, which was below the threshold for neuroprotection. However, astrocytes transiently exposed to DCG-IV or $4 \mathrm{C} 3 \mathrm{HPG}$ released a five- to sevenfold greater amount of TGF $\beta$ (TGF $\beta 1,-\beta 2$, or both), which may account for the protective activity of the glial medium. Finally, we proved that TGF $\beta$ was necessary for the neuroprotective activity of the glial medium by using antibodies against TGF $\beta 1$ or $-\beta 2$. Each of these antibodies abolished neuroprotection when applied to the medium collected from astrocytes treated with DCG-IV or 4C3HPG. Because the two antibodies are specific for their respective TGF $\beta$ isoforms, we conclude that the combination of TGF $\beta 1$ and $-\beta 2$ released in the glial medium reaches the threshold for neuroprotection or (more likely) that $\operatorname{TGF} \beta$ is released as a $\beta 1 / \beta 2$ heterodimer.

The glial medium acquires its neuroprotective activity at least $2 \mathrm{hr}$ after a transient activation of mGlu3 receptors, and neuroprotection vanishes after astrocytes are treated with the protein synthesis inhibitor cycloheximide (Bruno et al., 1997). Hence, we have considered the possibility that activation of glial mGlu3 receptors enhances the de novo synthesis of TGF $\beta$. TGF $\beta$ is synthesized as a dimer from the cleavage of a high molecular weight precursor (Massaguè et al., 1994: Flanders et al., 1998). A dimeric form of TGF $\beta$ containing TGF $\beta 2$ was detectable by Western blot analysis in cultured astrocytes, and its levels decreased with time after the cultures were incubated in the absence of serum (as we generally did in all experiments in which we collected the glial medium). Intracellular dimeric TGF $\beta$ increased substantially after the cultures were treated with DCG$\mathrm{IV}$, suggesting that activation of $\mathrm{mGlu} 3$ receptors enhances the de novo synthesis of TGF $\beta$. We cannot exclude the possibility, however, that $\mathrm{mGlu} 3$ receptor activation inhibits the degradation rate of TGF $\beta$ and that neuroprotection is cycloheximide-sensitive because it requires the synthesis of a different protein that is necessary for the accumulation and release of TGF $\beta$. It is noteworthy that an increase in intracellular TGF $\beta$ levels was also induced after transient activation of $\mathrm{A} 1$ adenosine receptors, 

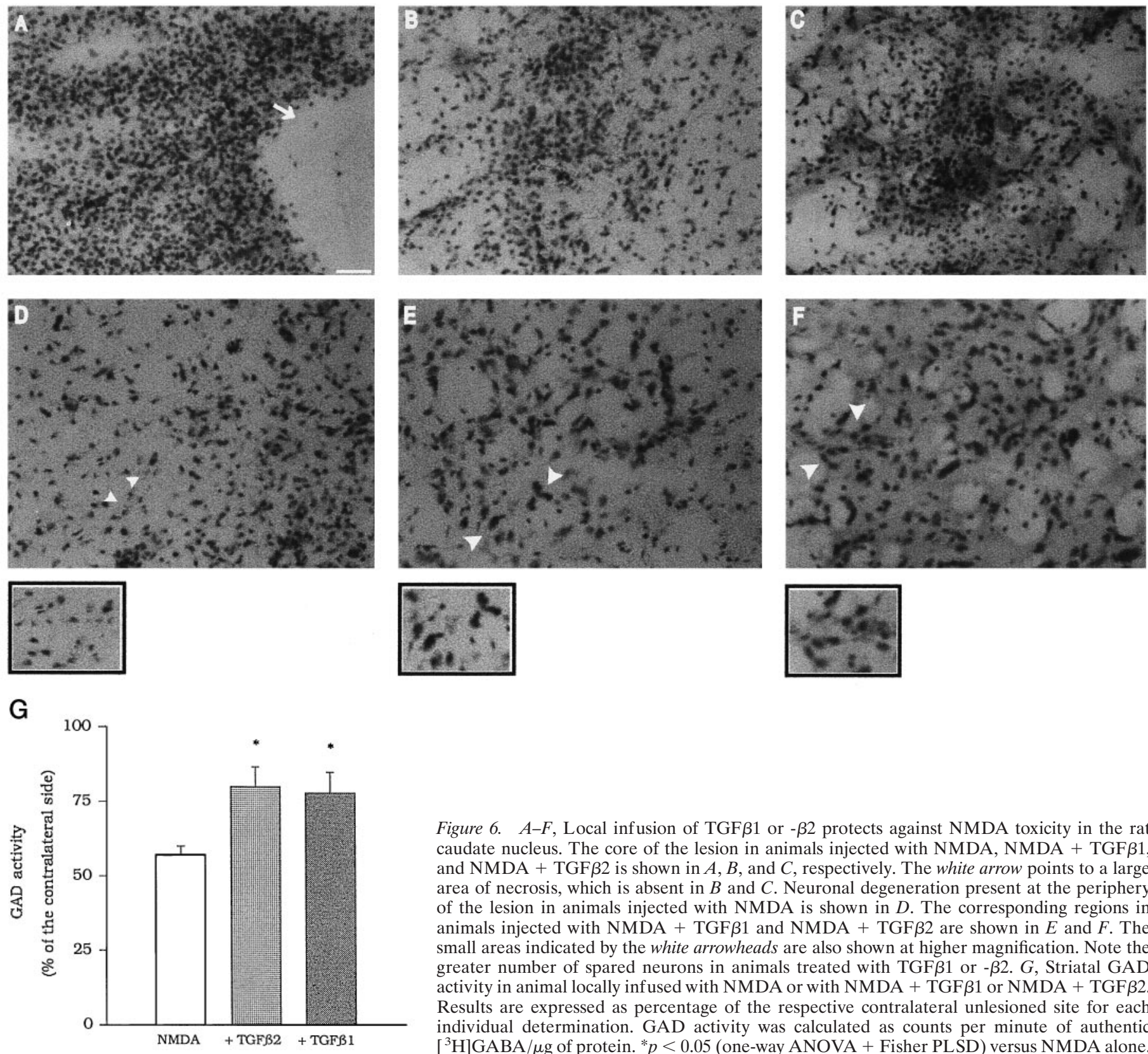

Figure 6. $A-F$, Local infusion of TGF $\beta 1$ or $-\beta 2$ protects against NMDA toxicity in the rat caudate nucleus. The core of the lesion in animals injected with NMDA, NMDA + TGF $\beta 1$, and NMDA + TGF $\beta 2$ is shown in $A, B$, and $C$, respectively. The white arrow points to a large area of necrosis, which is absent in $B$ and $C$. Neuronal degeneration present at the periphery of the lesion in animals injected with NMDA is shown in $D$. The corresponding regions in animals injected with NMDA + TGF $\beta 1$ and NMDA + TGF $\beta 2$ are shown in $E$ and $F$. The small areas indicated by the white arrowheads are also shown at higher magnification. Note the greater number of spared neurons in animals treated with TGF $\beta 1$ or $-\beta 2$. $G$, Striatal GAD activity in animal locally inf used with NMDA or with NMDA + TGF $\beta 1$ or NMDA + TGF $\beta 2$. Results are expressed as percentage of the respective contralateral unlesioned site for each individual determination. GAD activity was calculated as counts per minute of authentic $\left[{ }^{3} \mathrm{H}\right] \mathrm{GABA} / \mu \mathrm{g}$ of protein. ${ }^{*} p<0.05$ (one-way ANOVA + Fisher PLSD) versus NMDA alone.

which share with group-II mGlu receptors the coupling with the $\mathrm{G}_{\mathrm{i}}$ type of GTP binding proteins (for review, see Collis and Hourani, 1994). The $\beta \gamma$ subunits released in large amounts from trimeric $\mathrm{G}_{\mathrm{i}}$-proteins exert pleiotropic effects, including activation of adenylyl cyclase types II or IV, phospholipase C, or the MAP kinase pathway (for review, see Sternweis, 1994; Morris and Scarlata, 1997). Whether any of these intracellular pathways contributes to the production and release of TGF $\beta$ in response to mGlu3 receptor activation will be the subject of future investigation.

The protective activity of TGF $\beta 1$ or $-\beta 2$ against NMDA toxicity may provide new insights into the mechanism of neuronal degeneration. Both TGF $\beta$ and group-II mGlu receptor agonists protect not only against excitotoxic death but also against other forms of neurodegeneration, including neuronal apoptosis induced by $\beta$-amyloid peptide (Copani et al., 1995; Prehn et al.,
1996; Ren et al., 1997). One can therefore speculate that TGF $\beta$ prevents the execution of a pathway that is common to various forms of neuronal degeneration. TGF $\beta 1$ or $-\beta 2$ interacts with membrane receptors endowed with intrinsic serine/threonine kinase activity. Activation of these receptors leads to the phosphorylation of the latent transcription factor Smad2, which after complexing with Smad4 migrates to the nucleus where it activates gene expression (Massaguè et al., 1994, 1997). Established target genes of TGF $\beta$ are the "check points" p27 and p21, which produce growth arrest by inhibiting the activity of cyclin-dependent kinases (Datto et al., 1995; Ravitz, 1996). This mechanism may be relevant for the neuroprotective activity of $\mathrm{TGF} \beta$, because the induction of an abortive mitotic cycle has been causally related to the development of neuronal degeneration (Freeman et al., 1995; Herrup and Busser, 1995; Park et al., 1997a,b). Alternatively, TGF $\beta$ may act to inhibit the expression of cyclooxygenase-2 
(Minghetti et al., 1998; Pruzanski et al., 1998), an enzyme that is upregulated in response to synaptic excitation or $\beta$-amyloid peptide and is implicated in the pathophysiology of neuronal degeneration (Yamagata et al., 1993; Adams et al., 1996; Pasinetti, 1997).

In conclusion, activation of glial mGlu3 receptors may provide a mechanism for increasing the local production of TGF $\beta$ in the brain, thereby protecting neurons against various toxic insults. Through this particular mechanism, selective mGlu3 receptor agonists are expected to exert a wide-range neuroprotective effect without causing the side effects associated with use of NMDA or AMPA receptor antagonists, such as sedation, impairment of synaptic plasticity, ataxia, or psychotomimetic effects.

\section{REFERENCES}

Adams J, Collaco-Moraes Y, de Belleroche J (1996) Cyclooxygenase-2 induction in cerebral cortex: an intracellular response to synaptic excitation. J Neurochem 66:6-13.

Bruno V, Sureda FX, Storto M, Casabona G, Caruso A, Knopfel T, Kuhn R, Nicoletti F (1997) The neuroprotective activity of group-II metabotropic glutamate receptors requires new protein synthesis and involves a glial-neuronal interaction. J Neurosci 17:1891-1897.

Bruno V, Wroblewska B, Wroblewska JT, Fiore L, Nicoletti F (1998) Neuroprotective activity of $N$-acetylaspartylglutamate in cultured cortical cells. Neuroscience 3:751-757.

Buisson A, Choi DW (1995) The inhibitory mGluR agonist, S-4carboxy-3-hydroxyphenylglycine, selectively attenuates NMDA neurotoxicity and oxygen-glucose deprivation-induced neuronal death. Neuropharmacology 34:1081-1087.

Buisson A, Nicole O, Nouvelot A, MacKenzie ET, Vivien D (1997) Reduction of NMDA-induced toxicity by transforming growth factor$\beta 1$. Soc Neurosci Abstr 23:897.

Ciccarelli R, Sureda FX, Casabona G, Di Iorio P, Caruso A, Spinella F, Condorelli DF, Nicoletti F, Caciagli F (1997) Opposite influence of the metabotropic glutamate receptors subtypes mGlu3 and -5 on astrocyte proliferation in culture. Glia 21:390-398.

Collis MG, Hourani SMO (1993) Adenosine receptor subtypes. Trends Pharmacol Sci 14:360-366.

Copani A, Bruno V, Battaglia G, Leanza G, Pellitteri R, Russo A, Stanzani S, Nicoletti F (1995) Activation of metabotropic glutamate receptors protects against apoptosis induced by $\beta$-amyloid peptide. Mol Pharmacol 47:890-897.

Datto MB, Li Y, Panus JF, Howe DJ, Xiong Y, Wang XF (1995) Transforming growth factor beta induces the cyclin-dependent kinase inhibitor p21 through a p53-independent mechanism. Proc Natl Acad Sci USA 92:5545-5549.

Flanders KC, Ren RF, Lippa CF (1998) Transforming growth factorbetas in neurodegenerative disease. Prog Neurobiol 54:71-85.

Freeman RF, Estus S, Johnson Jr EM (1994) Analysis of cell-related gene expression in postmitotic neurons: selective induction of cyclin D1 during programmed cell death. Neuron 12:343-355.

Genazzani AA, L'Episcopo MR, Casabona G, Shinozaki H, Nicoletti F (1994) (2S, 1'R,2'R,3'R)-2-(2,3-dicarboxycyclopropyl)glycine positively modulates metabotropic glutamate receptors coupled to polyphosphoinositide hydrolysis in rat hippocampal slices. Brain Res 659:10-16.

Herrup K, Busser JC (1995) The induction of multiple cell cycle events precedes target-related neuronal death. Development 121:2385-2395.

Kane CJ, Brown GJ, Phelan KD (1996) Transforming growth factor- $\beta 2$ increases NMDA receptor-mediated excitotoxicity in rat cerebral cortical neurons independently of glia. Neurosci Lett 204:93-96.

Kingston AE, Bales KR, Monn JA, Paul SM, Pullar IA, Schoepp DD (1997) Comparison of the neuroprotective effects of mGluR agonists: (RS)-3,5-dihydroxyphenylglycine, LY354740 and L-amino-4-phosphonobutyric acid on ionotropic glutamate receptor-induced excitotoxicity in rat cortical neurons. Soc Neurosci Abstr 23:899.

Koh JY, Choi DW (1987) Quantitative determination of glutamatemediated cortical neuronal injury in cell culture by lactate dehydrogenase efflux assay. J Neurosci Methods 20:83-90.

Koh JY, Gwag BJ, Lobner D, Choi DW (1995) Potentiated necrosis of cultured cortical neurons by neurotrophins. Science 268:573-575.

Massaguè J, Attisano L, Wraba JL (1994) The TGF- $\beta$ family and its composite receptors. Trends Cell Biol 4:172-178.
Massaguè J, Hata A, Liu F (1997) TGF- $\beta$ signalling through the Smad pathway. Trends Cell Biol 7:187-192.

Minghetti L, Polazzi E, Nicolini A, Levi G (1998) Opposite regulation of prostaglandin E2 synthesis by transforming growth factor- $\beta 1$ and interleukin 10 in activated microglial cultures. J Neuroimmunol 82:31-39.

Morris AJ, Scarlata S (1997) Regulation of effectors by G protein alpha-, and beta gamma-subunits. Recent insights from studies of the phospholipase C-beta isoenzymes. Biochem Pharmacol 54:429-435.

Nicoletti F, Bruno V, Copani A, Casabona G, Knoepfel T (1996) Metabotropic glutamate receptors: a new target for the therapy of neurodegenerative disorders? Trends Neurosci 19:267-271.

Park DS, Levine B, Ferrari G, Greene LA (1997a) Cyclin-dependent kinase inhibitors and dominant negative cyclin-dependent kinase 4 and 6 promote survival of NGF-deprived sympathetic neurons. J Neurosci 17:8975-8983.

Park DS, Morris EJ, Greene LA, Geller HM (1997b) G1/S Cell cycle blockers and inhibitors of cyclin-dependent kinases suppress camptothecin-induced neuronal apoptosis. J Neurosci 17:1256-1270.

Pasinetti GM (1997) Cyclooxygenases and inflammation in Alzheimer's disease: experimental approaches and therapeutical implications. Abstract of the 36th Meeting of the American College of Neuropsychopharmacology (ACNP), Waikoloa, Hawaii, December.

Pellegrino JL, Pellegrino SA, Cushman JA (1992) A stereotaxic atlas of the rat brain. New York: Plenum.

Pin JP, Duvoisin R (1995) The metabotropic glutamate receptors: structure and functions. Neuropharmacology 34:1-26.

Prehn JH (1996) Marked diversity in the action of growth factors on $\mathrm{N}$-methyl-D-aspartate-induced neuronal degeneration. Eur J Pharmacol 306:81-88.

Prehn JH, Bindokas VP, Marcuccilli CJ, Krajewski S, Reed JC, Miller RJ (1994) Regulation of neuronal Bcl-2 protein expression and calcium homeostasis by transforming growth factor type beta confers wide ranging protection on rat hippocampal neurons. Proc Natl Acad Sci USA 91:12599-12603.

Prehn JHM, Bindokas VP, Jordan J, Galindo MF, Ghadge GD, Roos RP, Boise LH, Thomson CB, Krajewski SW, Reed JC, Miller RJ (1996) Protective effect of transforming growth factor- $\beta 1$ on $\beta$-amyloid neurotoxicity in rat hippocampal neurons. Mol Pharmacol 49:319-328.

Pruzanski W, Stefanski E, Vadas P, Kennedy BP, van den Bosch H (1998) Regulation of the cellular expression of secretory and cytosolic phospholipase A2, and cyclooxygenase- 2 by peptide growth factors. Biochim Biophys Acta 1403:47-56.

Ravitz MJ (1996) Differential regulation of $\mathrm{p} 27$ and cyclin D1 by TGF $\beta 2$ and EGF in C3H10T1/2 mouse fibroblasts. J Cell Physiol 168:510-520.

Ren RF, Flanders KC (1996) Transforming growth factors- $\beta$ protect primary rat hippocampal neuronal cultures from degeneration induced by $\beta$-amyloid. Brain Res 732:16-24.

Ren RF, Hawver DB, Kim RS, Flanders KC (1997) Transforming growth factor- $\beta$ protects human hNT cells from degeneration induced by $\beta$-amyloid peptide: involvement of the TGF- $\beta$ type II receptor. Brain Res Mol Brain Res 48:315-322.

Rose K, Goldberg MP, Choi DW (1992) Cytotoxicity in murine neocortical cell culture. In: Methods in toxicology, Vol 1, in vitro biological systems (Tyson CA, Frazier JM, eds), pp 46-60. San Diego: Academic.

Shigemoto R, Kinoshita A, Wada E, Nomura S, Ohishi H, Takada M, Flor PJ, Neki A, Abe T (1997) Differential presynaptic localization of metabotropic glutamate receptor subtypes in the rat. J Neurosci 17:7503-7522.

Sternweis PC (1994) The active role of beta gamma in signal transduction. Curr Opin Cell Biol 6:198-203.

Tanabe Y, Masu M, Ishii I, Shigemoto R, Mizuno N, Nakanishi S (1992) A family of metabotropic receptors. Neuron 8:169-172.

Tanabe Y, Nomura A, Masu M, Shigemoto R, Mizuno N, Nakanishi S (1993) Signal transduction, pharmacological properties, and expression patterns of two rat metabotropic glutamate receptors, mGluR3 and mGluR4. J Neurosci 13:1372-1378.

Winder DC, Conn PJ (1993) Activation of metabotropic glutamate receptors increases cAMP accumulation in hippocampus by potentiating responses to endogenous adenosine. J Neurosci 13:38-44.

Yamagata K, Andreasson KI, Kaufmann WE, Barnes CA, Worley PF (1993) Expression of mitogen-inducible cyclooxygenase in brain neurons: regulation by synaptic activity and glucocorticoids. Neuron 11: 371-386. 